\title{
Relationship of Knowledge with Readiness to Prevent the Occurrence of HIV / AIDS in Aliyah Guppi Students
}

\author{
Edison Siringoringo ${ }^{1}$, Amirullah $^{2 *}$, Nurlinda $^{3}$ \\ Departemen Surgical Medical Nursing , Stikes Panrita Husada Bulukumba, Indonesia ${ }^{1}$ \\ Departemen Surgical Medical Nursing, Stikes Panrita Husada Bulukumba, Indonesia ${ }^{2}$ \\ S1 Nursing Study Program, Stikes Panrita Husada Bulukumba, Indonesia ${ }^{3}$ \\ Corresponding Autor : Amirullahners@gmail.com*
}

\begin{abstract}
One of the viruses that is currently a concern of the world community, because it is considered very dangerous for the survival of a nation is the Human Immunodeficiency Virus (HIV). HIV is a virus that paralyzes the immune system so that it causes Acquired Immune Deficiency Syndrome (AIDS). AIDS stands for Acquired Immune Deficiency Syndrome is a disease characterized by damage to the body's defense system, so that sufferers are easily attacked by a variety of severe infections and unusual cancers. AIDS is caused by the Human Immunodeficiency Virus (HIV). The research design used in this study was observational analytic that is examining the relationship between variables. With a cross-sectional study approach. The population of all students of Madrasah Aliyah Guppi Gunung Jati. The sampling method in this study uses the Nonprobability Sampling method with the sampling technique was purposive sampling with a total of 48 samples based on the sampling formula from Isaac and Michael. Knowledge about HIV / AIDS from 48 respondents can be seen that the most on good knowledge are as many as 47 (97.9\%) respondents. Readiness to prevent the occurrence of HIV / AIDS is the most ready to prevent as many as $45(93.8 \%)$ respondents. There is no relationship of knowledge with readiness to prevent the occurrence of HIV / AIDS from the proposed hypothesis known $\mathrm{p}$ of 1,000 , when compared with an $\alpha$ value of $0,05(1,000>0.05)$.
\end{abstract}

Keywords: Human Immunodeficiency Virus, Acquired Immune Deficiency Syndrome

\section{INTRODUCTION}

Health is one of the important indicators in measuring the level of prosperity of a society or nation. The healthy paradigm that is currently being promoted requires a change of mindset, from treating illness to maintaining or maintaining health so as not to get sick. For this reason, community knowledge about various diseases and how to avoid or prevent them needs to be disseminated to them. Thus the community can consciously protect themselves and the people they care about from various viruses that attack (MOH RI, 2002). One of the viruses that is currently a concern of the world community, because it is considered very dangerous for the survival of a nation is the Human Immunodeficiency Virus (HIV). HIV is a virus that paralyzes the immune system so that it causes Acquired Immune Deficiency Syndrome (AIDS) (Nursalam, et al, 2007). 
AIDS stands for Aquired Immune Deficiency Syndrome is a disease characterized by damage to the body's defense system, so that sufferers are easily attacked by a variety of severe infections and unusual cancers. AIDS is caused by the Human Immunodeficiency Virus (HIV) virus (Manuscript, 2011).

The case of HIV / AIDS is an iceberg phenomenon, with far fewer people reported than is the case. This can be seen from the number of AIDS cases reported annually which has significantly increased. Besides AIDS is a very dangerous disease because it has a $100 \%$ CFR (Case Fitality Rate) in five years, meaning that within five years after being diagnosed the patient will die. Prevention of HIV / AIDS transmission is the responsibility of each individual, which is generally strongly influenced by knowledge factors (Murni, et al, 2009). Those who have a high level of knowledge of HIV / AIDS are getting better (Siwy, 2010). This was confirmed in a study conducted by Singale (2012) showing that $84.9 \%$ of 197 students of SMK Negeri 3 Manado were students who had high knowledge of HIV / AIDS. With this high level of knowledge, 73.7\% attitudes and $52.6 \%$ attitudes towards HIV / AIDS prevention are also obtained. Worldwide in 2013 35 million people were living with HIV which included 16 million women and 3.2 million children aged $<15$ years. The number of new HIV infections in 2013 was 2.1 million consisting of 1.9 million adults and 240,000 children aged $<15$ years. The number of deaths from AIDS was 1.5 million consisting of 1.3 million adults 190,000 children aged $<15$ years.

In Indonesia, HIV / AIDS was first discovered in Bali province in 1987. Until now HIV / AIDS has spread to 386 districts / cities in all provinces in Indonesia (Ministry of Health, Republic of Indonesia, 2014). Based on provincial reports, cases of HIV infection reported from 1987 to September 2014 for the province of South Sulawesi were 4,314 cases (Directorate General of PP \& PL Ministry of Health, Republic of Indonesia, 2014). Based on Bulukumba Health Dines data, it shows an increasing number of HIV / AIDS incidence in this Regency from year to year, namely: In 2013 it reached 113 people living with HIV, in 2014126 people living with HIV and in 2015 then reached 159 people detected with HIV / AIDS. Decree of the Coordinating Minister for People's Welfare No. 9 of 1994, which is one of the targets of information and education communication (IEC) on HIV / AIDS prevention and how to provide IEC to high-risk groups. Information about HIV / AIDS through this communication media can increase the knowledge of housewives who are at high risk of suffering from HIV / AIDS and the knowledge 
received is expected to be able to change sexual attitudes and behavior to prevent HIV / AIDS (Juliastika, 2012). Based on the description above, the writer is interested in conducting research on "The relationship of the level of knowledge with the readiness to prevent the occurrence of HIV / AIDS in MA Guppi Gunung Jati students

\section{MATERIAL AND METHODS}

The research design used in this study was observational analytic that is examining the relationship between variables. With a cross sectional study approach that is the type of research that emphasizes when measuring / observing data independent and dependent variables are assessed simultaneously at one time (Nursalam, 2013). Population is every subject (which can be human, experimental animals, etc.) that meets the specified characteristics (Suyanto, 2011). The population is the group that is the target of research (Notoatmodjo, S, 2011).

The population of this study is all students of MA Guppi Gunung Jati, amounting to 90 people. The sampling method in this study uses the Probability Sampling method with the sampling technique is Stratified random sampling meaning strata or the position of the subject (someone) in the community. The number of samples is 48 samples. Research instruments are written guidelines about interviews or observations or list of questions, which are prepared to obtain information from respondents (Hidayat, 2013). b. Bivariate test is performed to see the relationship of each element of the independent variable and the dependent variable, can be obtained through questionnaires analyzed using chi-square statistical tests with significance level $\alpha=0.05$ and if there are a number of cells that have an excpected count value $<5$, then it is done merging cells which are then tested again using the che square test.

\section{RESULTS}

Table 1.Characteristics of Respondents by Gender

\begin{tabular}{lcc}
\hline Gender & $\mathbf{n}$ & Percentage (\%) \\
\hline Male & 22 & 45,8 \\
Female & 26 & 54,2 \\
\hline Amount & $\mathbf{4 8}$ & $\mathbf{1 0 0}$ \\
\hline
\end{tabular}

Based on table 1 it can be seen that the characteristics of respondents based on gender there are 22 (45.8\%) respondents are male, and there are $26(54.2 \%)$ respondents are female. 
Table 2. Distribution of Respondent Frequencies Based on Students' Knowledge

\begin{tabular}{lll}
\hline Knowledge & $\mathbf{n}$ & Percentage (\%) \\
\hline Good & 47 & 97,9 \\
Not Good & 1 & 2,1 \\
\hline Amount & $\mathbf{4 8}$ & $\mathbf{1 0 0}$ \\
\hline
\end{tabular}

Based on table 2, the results show that respondents who have good knowledge are $47(97.9 \%)$ respondents and less knowledge is 1 (2.1\%) of respondents.

Table 3. Distribution of Frequency of Respondents Based on readiness to prevent HIV / AIDS

\begin{tabular}{lcc}
\hline Readiness to prevent HIV / AIDS & $\mathbf{n}$ & Percentage (\%) \\
\hline Ready & 45 & 93,8 \\
Not Ready & 3 & 6,3 \\
\hline Amount & $\mathbf{4 8}$ & $\mathbf{1 0 0}$
\end{tabular}

Based on table 3, the results show that 45 (93.8\%) respondents were ready to prevent HIV / AIDS and 3 (6.3\%) respondents were not ready to prevent HIV / AIDS.

Table 4 Relationship of Knowledge with Readiness to Prevent the Occurrence of HIV / AIDS

\begin{tabular}{|c|c|c|c|c|c|c|c|}
\hline \multirow{3}{*}{ Knowledge } & \multicolumn{4}{|c|}{ Readiness to prevent HIV / AIDS } & \multirow{2}{*}{\multicolumn{2}{|c|}{ Amount }} & \multirow{3}{*}{$P$ value } \\
\hline & \multicolumn{2}{|c|}{ Ready } & \multicolumn{2}{|c|}{ Not Ready } & & & \\
\hline & $\mathrm{n}$ & $\%$ & $\mathrm{n}$ & $\%$ & $\mathrm{n}$ & $\%$ & \\
\hline Good & 44 & 93,6 & 3 & 6,4 & 47 & 100 & 1,000 \\
\hline Not Good & 1 & 100 & 0 & 0 & 1 & 100 & \\
\hline Amount & 45 & 93,8 & 3 & 6,2 & 48 & 100 & \\
\hline
\end{tabular}

Based on table 4 above of the total 48 respondents, there were 47 respondents who were well-informed namely 44 (93.6\%) who were well-informed and ready to prevent the occurrence of HIV / AIDS and there were 3 (6.4\%) respondents who were wellinformed but not ready to prevent the occurrence of HIV / AIDS. 1 respondent who lack knowledge namely 1 (100\%) who lack knowledge but is ready to prevent the occurrence of HIV / AIDS and there are 0 respondents who lack knowledge and are not ready to prevent the occurrence of HIV / AIDS. The results of hypothesis testing using the Chi Square test showed a p value of 1,000, when compared with an $\alpha$ value of 0.05 , the results were greater $(1,000>0.05)$. This means that there is no significant relationship between knowledge and readiness to prevent the occurrence of HIV / AIDS in students of Madrasah Aliyah Guppi Gunung Jati.

\section{DISCUSSION}

The results showed that respondents who had good knowledge were 47 (97.9\%) respondents and less knowledge was 1 (2.1\%) respondents. The researcher's assumption states that the majority of students at Madrasah Aliyah Guppi Gunung Jati 
have good knowledge, but there is one student who lacks that knowledge because they rarely participate in health education activities including HIV / AIDS. Knowledge is the result of knowing, and this happens after people have sensed a certain object. The senses of the five human senses are the sense of sight, hearing, smell, taste and touch. Most of human knowledge is gained through the eyes and ears, the process of seeing and hearing. Besides through the eyes and ears, the process of seeing and hearing. Besides, the process of experience and learning process in formal and informal education.

Soekanto (2002) said knowledge is the result of tofu, an important domain in shaping one's actions (ovent behavior). Cognitive processes include memory, thought, perception, symbols of reasoning and problem solving. In the common Indonesian dictionary, knowledge is everything that is known that is related to something. Knowledge in the big Indonesian dictionary (1999) means everything that is known or everything related to the subject matter. The category of knowledge includes the ability to recall from memory specific and general things, methods and processes or remembering patterns, arrangements, symptoms or events. Based on the definition above it can be concluded that knowledge is a process of remembering and rerecognizing objects that have been learned through the five senses in a particular field as well. Thus what is meant by knowledge in this study are things that are known by students about HIV / AIDS.

This study is in line with the results of research conducted by Yani Wulandari and Intan Silviana Mustikawati (2013) at the Jakarta drug dependency hospital that 35 people (71.42\%) have poor knowledge of HIV \& AIDS, 10 people (20.40\%) have good knowledge of HIV \& AIDS, and 4 people (8.16\%) had low knowledge of HIV \& AIDS. They get this knowledge from print and electronic media such as television, radio, newspapers, brochures, etc., and get it from family or friends. However, they rarely attend counseling, seminars or discussions about HIV / AIDS. The results of research conducted by Juliastika et al (2011) in the city of Manado that 33 respondents with good knowledge and 38 respondents who have poor knowledge. The possibility of the respondents' low knowledge is due to the fact that there are still many who have not been exposed to information about HIV / AIDS and the level of knowledge is still at the application, analysis, and evaluation stages as explained by notoadmodjo (2010).

The results showed that 45 (93.8\%) respondents were ready to prevent HIV / AIDS and $3(6.3 \%)$ respondents were not ready to prevent HIV / AIDS. The researcher's 
assumption states that most students of Madrasah Aliyah Guppi Gunung Jati are ready to prevent the occurrence of HIV / AIDS and a small portion, 3 (6.3\%) respondents who are not ready to prevent the occurrence of HIV / AIDS because of the ignorant attitudes of some students, wrong mindset or no support from family. According to the Big Indonesian Dictionary (2007), prevention is the process, way, preventive action or restraining action so that something does not happen. Thus, prevention is an action. Prevention is synonymous with behavior. Thus what is meant by readiness to prevent the occurrence of HIV / AIDS is an effort of students in preventing HIV / AIDS from happening.

This study is in line with research conducted by Yani Wulandari and Intan Silviana Mustikawati (2013) at the Jakarta drug dependency hospital that 23 people $(46.93 \%)$ had good behavior towards preventing HIV \& AIDS risk, 21 people (42.85\%) had unfavorable behavior towards prevention of risk of HIV \& AIDS, and 5 people $(10.20 \%)$ have bad behavior towards the prevention of risk of HIV \& AIDS. The number of outpatients who have good HIV / AIDS risk prevention behaviors can be caused by the influence of health workers who always provide counseling about HIV / AIDS as well as the support of families to conduct HIV / AIDS risk prevention behaviors. The results showed that a total of 48 respondents, there were 47 respondents who were wellinformed namely 44 (93.6\%) who were well-informed and ready to prevent the occurrence of HIV / AIDS and there were 3 (6.4\%) respondents who were well-informed but were not ready to prevent HIV / AIDS. 1 respondent who lack knowledge namely 1 (100\%) who lack knowledge but is ready to prevent the occurrence of HIV / AIDS and there are 0 respondents who lack knowledge and are not ready to prevent the occurrence of HIV / AIDS. This is caused by the existence of other factors outside of knowledge which give a very big influence on the readiness to prevent the occurrence of HIV / AIDS such as the nature, mindset of the students themselves, attitudes and behavior of health workers in this case the counseling and family support.

'The results of hypothesis testing using the Chi Square test showed a p value of 1,000 , when compared with an $\alpha$ value of 0.05 , the results were greater $(1,000>0.05)$. This means that there is no significant relationship between knowledge and readiness to prevent the occurrence of HIV / AIDS in students of Madrasah Aliyah Guppi Gunung Jati. Knowledge is something that is very important to know in preventing the occurrence of HIV / AIDS. If a person has good knowledge about HIV / AIDS then the action to prevent 
it will go well. However, if a person does not have good knowledge about HIV / AIDS it will not work well (Notoadmojo, 2010). However, on the one hand knowledge is an element that plays the most important role in assessing a person's ability to behave in daily life, especially in accepting various things he receives both through the media and face to face with health workers (Sarwono, 2009). Thus what is meant by the relationship between knowledge and readiness to prevent the occurrence of HIV / AIDS in this study is whether there is a good relationship between the lack of knowledge students have with the readiness of these students to prevent the occurrence of HIV / AIDS.

This study is in line with research conducted by Yani Wulandari and Intan Silviana Mustikawati (2013) at the Jakarta drug dependency hospital that knowledge of HIV / AIDS outpatients in Jakarta drug dependence hospitals is poor as many as 35 people (71.42\%) and prevention behaviors at risk of HIV / AIDS in outpatients in Jakarta drug dependence hospitals that is good as many as 23 people (46.93\%) then it is concluded that there is no relationship between knowledge of HIV / AIDS with prevention of HIV / AIDS risk behaviors for outpatients in Jakarta drug dependency hospital. This is caused by the existence of other factors outside of knowledge which have a profound influence on HIV / AIDS risk prevention behaviors such as the relationship of individuals with family and social life, support for attitudes and behavior of health workers, the availability of props for health education, counseling and the ease of procedures such as free medical treatment for poor families. The results of a study conducted by Juliastika et al (2011) in the city of Manado that the knowledge of most respondents had less knowledge about HIV / AIDS (53.52\%) and good attitude towards the use of condoms (64.79\%). The results of the bivariate analysis showed that the knowledge variable was not significantly related to the attitude variable $(P=0.092)$. The possibility of the low level of respondents' knowledge and condom use is due to the fact that there are still many who have not been exposed to information about HIV / AIDS and the level of knowledge is still at the stage of understanding, not yet through the application, analysis, synthesis and evaluation stages.

\section{CONCLUSIONS}

There is no relationship of knowledge with readiness to prevent the occurrence of HIV / AIDS as evidenced by the proposed hypothesis known p of 1,000, when compared with an $\alpha$ value of $0.05(1,000>0.05)$. 2 . It is hoped that the community will be able to 
increase the public's knowledge, especially efforts to prevent the occurrence of HIV / AIDS. It is expected for parents that this research can be used as input for efforts to monitor and control children's behavior against HIV / AIDS.

\section{REFERENCES}

Depkes RI. 2002. Human immunodeficiency virus. dalam http //www.depkes.go.id diakses 1 februari 2016

Dharma, Kelana Kusuma. (2011). Metodologi Penelitian Keperawatan. Trans Info Media: Jakarta. Hidayat, Aziz Alimul. (2010). Metode Penelitian Keperawatan Dan Teknik Analisis Data, ed. 1. Jakarta : Salemba Medika.

Juliastika (2011). Hubungan pengetahuan tentang HIV/AIDS dengan sikap dan tindakan pengunaan kondom pada pria pada wanita pekerja seks di kota Manado.

Kristawansari. (2013). Hubungan Antara Pengetahuan dan Sikap Sopir Truk Tantang HIV/AIDS Dengan Perilaku Pencegahan HIV/AIDS (Studi Kasus Di Area Pangkalan Truk Alas Roban Kabupaten Batang Tahun 2012), Vol. 2 (3), Hal. 1-9.

Lestari, Titik. (2015). Kumpulan Teori Untuk Kajian Pustaka Penelitian Kesehatan, ed. 1. Yogyakarta: Nuhamedika.

Naskah, Tim Dapur. (2011). Penyakit AIDS, ed. 1. Bandung : Sarana Ilmu Pustaka.

Notoadmodjo, Soekidjo. (2010). Ilmu Perilaku Kesehata. Jakarta : Rineka Cipta.

Notoadmodjo, Soekidjo. (2010). Metodologi Penelitian Kesehatan, ed. Rev. Jakarta : Rineka Cipta.

Noviana, Nana. (2013). Catatan Kuliah Kesehatan Reproduksi HIV-AIDS, ed. 1. Jakarta : TIM.

Nursalam. (2011). Konsep Dan Penerapan Metodologi Penelitian Ilmu Keperawatan, ed. 3. Jakarta : Salemba Medika.

Octavianty, Lenny. et.al., (2015). Pengetahuan, Sikap dan Pencegahan HIV/AIDS Pada Ibu Rumah Tangga. Vol.1 (2015), Hal. 53-58.

Pujiartanti, (2012) Pengaruh Pengetahuan dan Sikap remaja tentang kesehatan reproduksi dalam program PIK-KRR (pusat informasi dan konseling kesehatan reproduksi remaja) terhadap perilaku kesehatan reproduksi remaja di SMAN 02 Rambah samo Kabupaten Rokan hulu tahun 2010.

Restianti, Hetti. (2009). Memahami Penyakit Menular Seksual (PMS), ed. 1. Bandung : Puri Pustaka.

Setiadi, ( 2012 ). Konsep dan Praktik Penulisan Riset Keperawatan. Edisi 2. Yogyakarta : Graha Ilmu

Singale, Lastianti. (2012). Hubungan Antara Pengetahuan Dan Sikap Tentang HIV/AIDS Dengan Tindakan Pencegahan HIV/AIDS Pada Siswa SMK Negeri 3 Tahuna. 
Sugiyono. (2012). Metode Penelitian Kuantitatif, Kualitatif Dan R\&D, ed. Rev. Bandung: Anggota Ikatan Penerbit Indonesia (IKAPI).

Wawan \& Dewi. (2011). Pengatahuan, Sikap dan Perilaku Manusia, ed. 2. Yogyakarta: Nuhamedika.

Wulandari, Yani \& Silviana, Intan. (2013). Hubungan pengetahuan tentang HIV/AIDS dengan perilaku pencegahan beresiko HIV/AIDS pada pasien rawat jalan di rumah sakit ketergantungan obat Jakarta. 